\title{
Who, being in the form of God, did not consider it robbery to be equal with God: Kenosis of leadership
}

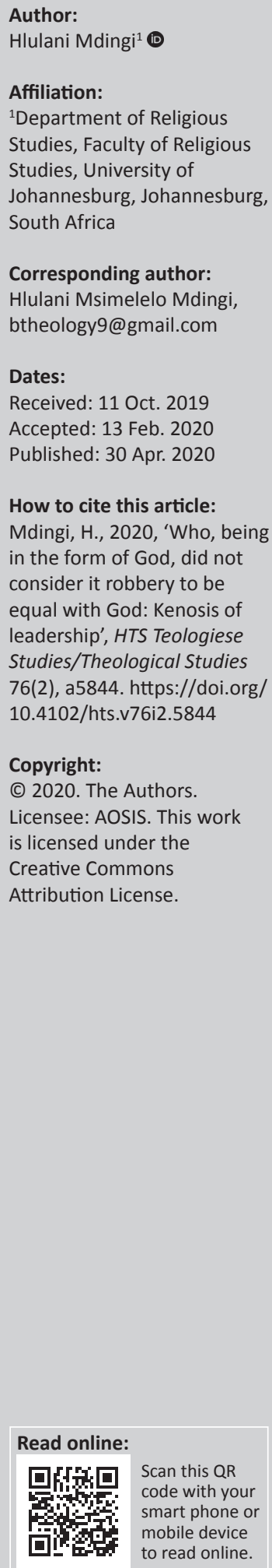

Leadership is at the core of Christianity; it operates from the paradigm of God's revelation to humanity through creation. The creation of the world and the creation of Imago Dei are markers of the service that God has maintained from creation to the fulfilment of soteriology (Gn 1:26, 3 and I Cor 15:42). The early church's worship of Christ, at least in the Didache, stemmed from the fact that this Hebrew prophet was a servant of God and was $Y H W H$ in the flesh. The early teachings of the church were service to the world. This article contends that Christianity faces a crisis because of neglect of the nuclei of Christian theology and faith oriented around the real or physical person of Christ and service to others. The emphasis of this article focuses on kenosis as a prerogative of true Christian faith and leadership. A kenotic model of leadership is service to humanity and the world. The article seeks reflection on the theological importance of kenosis, which interacts with creation and creature. This approach will highlight underlying theology for leadership as it relates to the person of Christ.

Keywords: Leadership; Kenosis; Incarnation; Christology; Soteriology; Black theology.

\section{Introduction: Why Kenosis}

Christian leadership is an important topic for both the church and the secular world. Developing countries in Africa that have cast off the white man's burden, that is, colonialism, slavery, imperialism and apartheid, and remained Christian should redefine their Christianity, to voluntarily serve in the world of abject suffering. They need to discover the depths of their own Christology, which is ontological and practical. The need for a new interpretation based on experience, especially in Africa, would encourage a different model of leadership, which is based on experience and human values towards each other. This research seeks to appeal to key theological concepts concerning the person of Christ for the subject of leadership. The black people experience especially the kind of Christianity that emerged from the inspiration of non-Christian African forefathers that inspires churches, such as African Indepedent Churches, to provide a landscape of blending of redemption, liberation and leadership within creation. Human beings receive a call from nature and God (see Daneel 1999: 209). As such, God as the poured out life-giving spirit indicates a kenosis blended in nature. This point is important to motivate the intricacies of kenosis, nature and Christ becoming flesh. God becoming flesh addresses nature, history and the political context.

To address Christian leadership, the research will focus on the concept of kenosis. Kenosis provides the theoretical basis for thinking about Christian leadership. The importance of looking at a kenotic model for leadership stems from the deep theological reflection, which kenosis can serve for both reflection and praxis. The research seeks to establish the metaphysical origin and practical application of kenosis. How it is demonstrated in the life of Christ? The humanity of Christ is central for kenosis, leadership and in reflecting what lengths the last Adam suffers to redeem the souls, behaviours and material conditions of the saved. Kenosis underlines the Godhead and the heart of the Godhead with interacting with the world. As such, creation is central in discussing the love of God and kenosis that leads to creation and redemption through the cross (Col 1:15-17). Thus, creation is important in reflecting God's love because the world, biologically and existentially, comes with suffering. Rolston (2001) discusses kenosis and nature to establish the relationship of a loving God and biological systems, which are not benevolent. Rolston (2001) asserts:

Biological nature is always giving birth, regenerating, always in travail. Something is always dying, and something is always living on. 'The whole creation has been groaning in travail together until now' (Romans 8:22). Perhaps we can begin to recognize in creative nature dimensions both of redemptive and of vicarious suffering, one whereby ongoing success is achieved by sacrifice. (p. 58)

Note: Special collection entitled Christian Leadership, sub-edited by Wessel Bentley (UNISA). 


\section{Rolston (2001) further argues:}

There is a great divine 'yes' hidden behind and within every 'no' of crushing nature. God, who is the lure toward rationality and sentience in the upcurrents of the biological pyramid, is also the compassionate lure in, with, and under all purchasing of life at the cost of sacrifice. Long before humans arrived, the way of nature was already a via dolorosa. In that sense, the aura of the cross is cast backward across the whole global story, and it forever outlines the future. (pp. 59-60)

While there are multiple approaches to Christian leadership, the concept of kenosis weaves together the Creator, creation and creatures. Kenosis entails suffering and sacrifice. This suffering and sacrifice become the starting point for any form of Christian leadership and fit into creation. Le Poidevin (2013:226) noted that the Son's subjection to the will of the Father is a direct indication of the Son entering human flesh and nature. The Son enters creation and its circles to suffer and sacrifice in for love to prevail. The descending of the Son carries a deep meaning of obedience, human obedience. Thus, human beings, laity, pastors, theologians and the general populous must accept great pains of suffering, obedience and sacrifice in leadership. This research will start by developing a picture of the God and human relation of Christ to formulate a conception of leadership that leans towards the person of Christ. The person of Christ through kenosis is a base for the true formation of Christian leadership. Philippians 2:5-11 provides insights into the mental framework Christians should have; it also establishes the identity of Christ before the world began.

\section{Kenosis as love}

Kenosis means self-emptying (Phlp 2:5) and is important for Christian theology; it is a concept, which can assist, socially and behaviourally, the church and Christians in the world. Kenosis provides the selfless attitude believers should have despite the suffering in the world. Rolston (2001:44) has pointed out the traits of kenosis that influence natural order despite the ruthlessness of natural systems. However, what is central in his argument is the close links of suffering and sacrifice in biological systems. Suffering is essential in the world as it defines the evolutionary coding of cosmic, biological and existential makeup of the genes. Rolston (2001) asserts:

If one compares the general worldview of biology with that of theology, it first seems that there is only stark contrast. To move from Darwinian nature to Christian theology, one will have to change from the sign of natural history, from selfish genes to suffering love. (p. 43)

Carson (1975:549) observed that 'only a suffering God can save us'. Pardue (2012:273-275) notes that the various reception of kenosis include understanding the humility of God and the primary characteristic of the Godhead from eternity. Kenosis provides philosophical, theological and ethical insights. ${ }^{1}$ Through kenosis, we engage the fundamental

1.Pardue $(2012: 274-276,278)$ notes the other discourses that are entailed in the concept, bringing up the dangers of kenosis or humility in areas of abuse and gender. However, he notes that other feminist discourse sees kenosis as instrumental for both men and women. ingredients that shape soteriology and the redemptive process, which lays before the foundation of the world. The love of God for creation is channelled from eternity and is apparent in God's humility and God assuming flesh to be fully bound to humanity; Christ is an ecclesiastical celebration of the soteriological embodiment of the Divine in Imago Dei evident in the Incarnation. Doncel (2006:5) explains kenosis in relation to God's love and its link to human beings as cocreators with God. However, the central point of kenosis is bound in love that is at play in the Trinitarian union (Doncel 2006:5). This love in the Trinitarian union meant that Christ ought to be like us in all things (Le Poidevin 2013:215). The role of love as central to the Creator and creation leads to a serious existential need of conceiving God and the workings of God in the world and in humans.

\section{Kenosis: Fully God and fully human}

The love of God is physically manifested in the incarnation. The incarnation has been abstract and speculative. The Christian creeds and ancient Christology ignore the deep insights, which can be deduced in the physiology of God becoming human. Carson (1975:543) pointed out that Chalcedonian Christology is under attack because of neglecting the humanity of Christ. The current context requires that Christ is felt and known as a human being. When Christ is accepted as a human being, there is no need for anyone, especially Christian leaders, to be placed on pedestals. The humanity of God removes speculation and signifies God historically being present in the world. Le Poidevin (2013:214) pointed out that medieval theologians view the incarnation metaphysically as opposed to ethics. He (2013) argues:

The Christ of medieval theology has all the perfections of a divine being. He is, for example omniscient. But the Jesus of the Gospel does not appear to be omniscient. (p. 214)

Black theology, which emphasises on the existential reading of God being human, suggests a radical rejection of speculation, abstraction and a theology that is removed from human experience. Cone (1993:13) pointed out that some scholars see the cross through philosophical and metaphysical speculation. The humanity of Christ is essential for Christian leadership as it is indicative of the role the flesh plays in the person of Christ. Carson (1975) argues:

In spite of the fact that, virtually from the beginnings of the early church, popular conceptions of the Incarnation have expressed the Christian conviction that the invisible, incomprehensible, impassible God has become visible, comprehensible, and passible in the historical Jesus, Christian theologians have, with scarce variation, been prohibited from theoretically affirming a full Incarnation by two factors: that of the immutability of God, and that of the incapacity of the human vehicle of God, the flesh, to manifest him adequately and fully. (p. 544)

The full and adequate representation of God in Christ means that God expects humans to follow the fragile, biological, social, political and existential humanity of Christ. The fleshiness of God in the person of Christ should not only refer to Christology but also imply a serious responsibility to all living flesh. The humanity of Christ does not exonerate human 
error. Instead, it gears up human beings to the full expression of humanity, rooted in the self and others. Pardue (2012) notes that kenosis can renew theology and understanding power; he argues:

The foundational relationship between Christ's self-giving and Christian baptism, furthermore, means that Christians must constantly struggle individually and corporately to understand how best to respond to the phenomenon of creaturely power. (p. 276)

Thus, the incarnation and kenosis provide a clear glimpse to the new redemptive identity human beings have in Christ and the ethical responsibility of power. The Christian church, especially with regard to leadership, should learn from the ministry and person of Christ. Clifford (2004:29) best expressed this through double kenosis, which means the unity of the divine and nature in Christ and the divine and nature in the church - human beings. He (2004) asserts:

\begin{abstract}
Adopting the framework of 'double kenosis', we keep before us the sacramental character of the Church. Indeed, Vatican II teaches that the Church is a mystery imbued with hidden presence of God, whose Spirit gives it life and guides it. By its union with Christ, the head of the body, the Church becomes a sign and instrument of the communion that God desires for all humankind. At this level, communion among members of the church and with others flows from participation in the kenotic love of Christ, in the outpouring of love that characterizes the communion of the three divine persons in the Trinity. (p. 30)
\end{abstract}

Double kenosis provides a sacramental and existential life of the person of Christ present in the church. The bodily life of Christ continues in the bodies of believers; his life and character become ours. The church becomes the body, which defines full humanity and full divinity. The kenotic leadership is biblical in conception and provides an epistemological tool for Christian theology and Christian praxis. The incarnated messiah who through kenosis is found as a slave, a political position, reveals the line and ethical-theological dimensions of human leadership. Kenosis in Philippians 2 points to kenosis occurring in the aseity of God, which seems to be ethical, personal and practical. This kenosis is hidden from creation although fundamentally knitted into creation. Kenosis is linked into modes of self-manifestation between the chain of Creator, creation and creatures. Doncel (2006) argues:

We can imagine the kenosis of the Creator as a 'self-restriction' in His divine being, freely fulfilled in loving respect for the creatures to be created, in order to offer them metaphysical play, to exist and to act as autonomous created beings. We specifically conceive that the triune God, 'before' His decision to create the universe, freely accepted to be 'no longer' the 'sufficient condition' of every particular effect. (p. 6)

God's self-restriction is not only a philosophical and intellectual appeal concerning the Godhead's act in the soteriological process. However, this self-restriction is practical in form, informing ethical and selfless behaviour before time - a behaviour that is inherited in space and time, with humans, as the agents of selflessness and humility. As such, reflection on kenosis, for behaviour and morals, implies that the foundations of kenosis as a trait for Christians are metaphysical, transcendent, moral and existential in nature. Christian theology emanates through the annals of the Hebrew faith and the religious roots of the Ancient Near Eastern religion. Hebrew theology appears as shifting and moulding itself based on material conditions and generational continuums of the covenant with $Y H W H$. In Christian theology, this covenant is historical but also occurring in the Godhead before time. The incarnation becomes a more explicit intervention of God in the world. Pardue (2012) asserts:

Like Athanasius and others before him, Augustine viewed the incarnation as the culminating event capping a slew of attempts by God to teach humility by example. Every instance of what we might call revelation involved a certain degree if condescension designed specifically to coax humans out of their wayward habits of life. Yet Augustine simultaneously recognises in the incarnation a unique occurrence in which the God of Abraham, Isaac and Jacob stoops to unthinkable depths for the purpose of shocking humanity from its persistent stupor. (p. 278)

The writings of the New Testament based on credal confessions, doxology, development of the dogma of the Christian ecclesia and the early Christian community (see Doncel 2006:6) build upon the Old covenant. Pauline theology and Christology focus on the predestination of salvific scheme of the workings of the God of the Hebrews. In the Book of Acts, Paul sets out to give a genealogical setting to the appearing of the messiah - an evocation of a leadership line emerging from God, history and genealogy. The metaphysical leaning of Christian theology confirms the transcendence of God in the realm of both the known and the unknown. Pauline theology unveils the transcendent God in an appearance of God as Imago Dei. Furthermore, the reconciliation between what was in the beginning of the foundation of the world is sealed by blood and the cultic role of the cross for salvation and for true human identity as creatures before God and creation (Eph 1:3-6).

Le Poidevin (2013:219) raises fundamental arguments concerning the depths of kenosis and how kenosis relates to the nature of God. He proposes a reflection on God as necessity and humans as contingent and raises questions on what identities may arise when considering the Son of God (necessity) and Jesus from Nazareth (contingent) for the faith. Le Poidevin correctly points out that Jesus, the contingent, and the Son of God (necessity/first cause) express the 'possibly possible'. The 'possibly possible' means that God can choose to assume anything, even if it disturbs our metaphysical views concerning the nature of God. Le Poidevin (2013:219) asserts: 'The kenoticising move then propose that we replace "necessary" as the essential property with "necessary-unless-freely-choosing-to-be-otherwise". Le Poidevin (2013) further argues:

Perhaps, in attempting to disentangle these metaphysical issues associated with the Incarnation, we invite the same criticism that Gore levelled at the medieval theologians that our overconceptualisation notion of God the Son has touch with the picture of Jesus that emerges from the Gospels. (p. 225) 
The appearance of God as human points to a teleological responsibility and role for human beings, self-emptying service for the ecclesia. The form of God, which is laid aside for the incarnation, seeks to demonstrate the balance between the human and divine, flesh and omniscience. Carson (1975:546547) noted that in Christ, kenosis occurred without blending or mixing of the divine and human natures. Thus, Christ is an adequate image of God and image for humanity. The incarnation is existential for creation and for the world filled with suffering. Moreover, the adoption of believers through the Spirit and Christ reaffirms the Edenic setting of human beings called into existence to co-create, lead and toil the land with an omnibenevolent, omnipotence and omnificent God (see Doncel 2006:11). Paul posits that the Spirit confesses in our spirit and creation groans as a woman in labour pains for the revealing of the sons of God $(\operatorname{Rm} 8: 19 \& 22)$. The theological roots concerning the origins of human being stress the reading of the biblical text (Genesis) and the soteriological process that God's transcendence and immanence, which are posited in humans, assemble kenotic leadership as flowing spatially in the fabric of existence. God's self-restriction process is a set standard for ethic and for Christian leadership. As such, the Christian ecclesia is a symbolic reigning of the sons of God. Christians have been justified and predestined before the foundations of world and have all been called to lead. Sharing the eternal bond of love that flows across and in exchange from the divine persons. Service underpins Christian leadership and kenosis, Christ incarnates to serve and the church inherits this selfless service to others. The existential context that finds the orientation of human beings, their formative development and their daily activity becomes the ambience for leadership. Kierkegaard and Lowrie (1941) asserts:

Man is spirit. But what is spirit? Spirit is the self. But what is the self? The self is a relation which relates itself to its own self, or it is that in the relation [which accounts for it] that the relation relates itself to its own self; the self is not the relation but [consists in the fact] that the relation relates itself to its own self. Man is a synthesis of the infinite and the finite, of the temporal and the eternal, of freedom and necessity, in short, it is a synthesis. A synthesis is a relation between two factors. So regarded, man is not yet a self. (p. 9)

Kierkegaard's assertion that the human is not yet the self propels the importance of the existential within the grandeur of creation before a transcendent God. The self, complete or incomplete, continues to mould, develop and form in the world, for Christians the soul is guided by God. As such, Christians are led to completion, which God established through creation and predestined soteriology. Soteriology, while revealed in the church, is actually existential pains, groanings and rumblings of the transcendent plan for the existential necessity of the revealing of the sons of God. The incarnation of the son of God occurred within created time, thus stressing the importance of humility, leadership and the existential context that include culture, history and belief. The sons and daughters of God emanate from humility and their neglect of prestige. The area of biology, which is in created time, gives a clear insight to understanding the solidarity of God with the poor, humanity and in giving direction to generations to come. Rolston (2001:43) has pointed out that nature has no kenosis, rather nature is highly competitive. Rostlon notes that despite the biological position of selfish genes theory, there remains an abstract element in the workings of the world. The lesson one draws from the lack of kenosis in nature is that the love and humility of God existed prior to nature; nature is the ambience; however, love remains flowing and prisms from the divine to the world. However, biology can provide a Christological model for soteriology, inheritance and lineages. Rolston (2001) argues:

When an organism is faced with defending similarities against differences, in competition with others of its species, with different alleles, each organism has been called to defend its kin and therefore its similarities in offspring and relatives. That way, if its alleles have a survival advantage, the fittest (best-adapted) will survive. (p. 46)

\section{He (2001) further asserts:}

Genes are a flow phenomenon. The genes are caught up in an impulse to thrust through what they know vitally to the next generation, and the next, and the next. Genes live in a lineage, dynamically evolving over time. (p. 47)

Rostlon's views give insight to the fact that the kenosis preceding the incarnation is the abstract working of God. In this regard, biology provides the deep consensus of the solidarity of God with human beings in the flesh, Christ being human on a molecular, subatomic and genetic level. The suffering and the ministry of Christ are a lineage line passed over to the church, those bought by his blood. The facts of biology can be used allegorically to mean that while a favourable environment allows evolution to occur. The environment exacts some kind of pressure, which will require the survival of the fittest genes. However, if God incarnates in the context of the poor, where environment and evolution should easily eliminate the poor, God transforms the environment and the biological significance of the environment. Similarly, a strong Christian church can transform societies despite positionality. Thus, Christ human manifestation on earth indicates the love of God before biology and within the set modes of biology. The daughters and sons of God are Adamic; they follow the last Adam who is revealed in suffering, obedience, death and resurrection. Christian soteriology is the conveyer belt into the self. It is the emptying, becoming nothingness and self-giving yourself to others.

Authentic Christian leadership, when viewed from kenosis, can bind the real outpouring of God in the flesh, omnibenevolence and the necessity of creation. The Hebrew conceptions of the messiah are fundamentally built into the system of creation and Imago Dei, a human agent transforming society. Clifford (2004:25) notes the dangers of the two-stage theory of kenosis often linking the incarnation and glory. Clifford notes that kenosis is not restricted to the incarnation or the role of servant, but in the fact that Christ took seriously the human condition. The seriousness of the human condition is evident in his ministry leading to death. Clifford (2004) argues: 
Briefly, the classical texts seem to contrast Paul's use of the term kenosis - which signifies emptying, or depletion - of the present Word of God in view of the Incarnation, with the exaltation and full manifestation of his Christ's glory in the Resurrection. Without abandoning the divine nature, Christ is emptied of the divine condition to assume a human nature, the condition of a slave, where the divine attributes are hidden, as it were. The fullness of Glory that was renounced in act of divine condescension is only revealed to us fully in the Resurrection. (p. 24)

Adam was placed in the garden, as a metaphor the Christian ecclesia is the Edenic expression of human teleos and directs us to the historical necessity of a messiah - God-man. The necessity of a messiah becomes a basis for a new covenant with $Y H W H$ through the God-man. Christian theology and Christian faith leap into the revealed truth that the messiah is the God-man. The eschatological visions leading to the establishment of an egalitarian society on earth reflect the role of God and the human agent. Christian leadership needs to be removed from idyllic settings, such as a Christian virtue of being 'humble' or in fact powerlessness (see Kessler 2010:535). God's humility occurred in the Godhead, but the humble Lamb of God chastised his religious, political and economic context. The incarnation is an existential disturbance to idyllic transcendence and omnipotence. The roots of Christian faith confirm the calling of Abraham to be a progenitor of nations, and being chosen by God signals the continual outpouring of God's presence to shaping history.

The Adamic setting that places creation, the fall, Christology and redemption on the centre stage of the divine and existential drama validates the relationship between the son of God and the sons of God. It amplifies etymologically and praxis the messiah (Melek ha-Mašīah) and the anointing (mashach) that Christian receive as a seal from God and a navigator to follow Christ - a sense of Imitatio Dei. The biblical text in Genesis (1:26-28 NKJV) implication of authority and being created in the image of God, an image that God will manifest on earth, points to the thematic leanings of Christology and soteriology. The Psalmist (8:4-6 NKJV), on the contrary, is struck by God's majesty, which brings within the Psalmist a deep sense of reverence and humility. The humility of God to create the world inspires the Psalm and brings the psalmist to humility, humility knitted in the grandeur of creation. This Psalm in Talmudic and Rabbinic Judaism (usually defined as the Torah was not given to ministering angels') gives significant insight to human agency and how even the law is given as a guide to imperfect people who strive at perfection - a link between Kierkegaard synthesis and self-formation. This point is crucial for understanding leadership as service of imperfect people that are striving towards good in God's kingdom. Christine Hayes (2017) points out that למלאכי תורה נתנה לא - the Torah was not given to ministering angels - is understood as follows:

The phrase seems to be predicated on two basic assumptions. First, it rather plainly assumes that humans and angels are distinct and perhaps even discontinuous. Second, the phrase would appear to discourage aspirationalism, to be an excuse for leniency, for lowering expectations, a concession and accommodation to human imperfection and inadequacy rather than a spur to virtue. Humans need not aspire to an angelic perfection because, after all, they are not angels and the Torah does not make extraordinary demands upon its recipients. This is indeed how the phrase is generally glossed in both scholarly and traditional Talmudic commentaries alike, as well as in popular Jewish literature. (pp. 123-124)

Thus, it can be deduced that leadership is part of being Godlike while in our humanity. To express true, moral, ethical and servant leadership is an expression of our creatureliness that is dependent on God and abiding by his principles. Pardue (2012:277) notes that the Augustinian conception of kenosis revolves around limits and restrains. However, limitation and restrain are empowering. Pardue (2012) asserts:

Thus, Christ's humility is not only what moves him to become incarnate and crucified (restraining), but also what allows him to live a life perfectly animated by the Spirit (empowering). Similarly, while divine speech inevitably requires of God a degree of self-limitation, it simultaneously works to grace a human instrument so that it produces an abundance beyond its normal capacity. (p. 277)

Kenosis entails serious suffering, love and obedience. The person of Christ represents suffering, love and the character traits of being a leader. The physiological body of Christ assists us to know that God is revealed in a biological body and expects service to him and others while embodied in this body.

Christology, more specifically the binary between full humanity and full divinity, forms the ambience of discourse. The humanity of Christ is the existential navigator, rooted and imbued in the theological significance of Imago Dei. The body of Christ, socially and genetically, assumes history and fragility; the omnibenevolent God actively participates in creation and with human beings, and thus, the flesh is emblematic that God is not an idol - sitting somewhere in heaven. Ruether (1983) argues:

With Jesus' death, God, the heavenly Ruler, has left the heavens and has been poured out upon the earth with His blood. Anew God is being born in our hearts to teach us to level the heavens and exalt the earth and create a new world without masters and slaves, ruler and ruled and subjects. No not even men come first with women behind in meek servility. (p. 9)

Cone (1993:12) asserts: 'For in the deaths of the poor of the world is found the suffering and even the death of God'. The full divinity of Christ becomes an affirmation of God's workings in human beings. Thus, the Epistle to the Philippians posits the intention of God in participation as beginning in the heart and mind of God before time and the foundations of creation. While there is speculation of the kenosis moment from the singular conception of God in the Hebrew religion, Trinitarian concepts of God and scholarly, there remains the ethical basis of kenosis, which binds Christians. God humbled himself in secret and in public, humility and limitation, to all forms of time is carried out in the transcendent and existential encounter. 


\section{Kenotic ecclesiology: Interiors and exteriors of Christian leadership}

Kenotic ecclesiology (Clifford 2004:26) is the engagement of the church and the world. The incarnation is inherited theologically and practically; it becomes the inherited nature and person of Christ for the church. The church has to seek the theological hermeneutics of the faith. Kenosis provides an ontological basis of the faith with the incarnation occurring among the poor. God favoured the poor to be the material revelation of God's being, majesty and redemptive work (Phlp 2:7). The early Christian creeds depict a poured out worship to the servant of God, Yeshua from Nazareth. The worship of Yeshua as servant is because of his obedience until death and he is Lord because of his resurrection (Phlp 2:811). Obedience, selflessness and adhering to the promises of God are central for our faith. Furthermore, they serve as insights to the early church, which is a kingdom of servants, kings and priests. The hierarchy of leadership in Christian theology and the Christian faith is a triad status between servitude, the priestly office and royalty. The context of John 13 records the washing of the disciple's feet and embalms forever humility as the greatness of those who are in the kingdom of God. This attitude of mind, heart and bodily is incubated in Christian faith. Obedience is fundamental as a principle for kenosis and reveals why Christ is Lord and Leader of creation and the church (Clifford 2004:30-31). Current abuses occurring in the church, some that are historical (the church as an institution of oppression), reveal the need of a theologically sound teaching on the person of Christ. A teaching about Christ teaching believers to know that humility is personal, private and hidden before displayed in public service.

This realisation suggests that on a deeper level, conception of Christian leadership is beyond having the right attitude. Christian leadership, which often entails liturgical practice of conducting service, sacraments and sermons, has become the point of convergence between the truth and deceit behind leadership. While it is imperative that a Christian leader attends to the public ordinances of the church, the leader must have a hidden and personal relationship with God. A silo for his or her kenotic acceptance to lead the flock with deep selflessness and self-emptying. This space of isolation allegorically mirrors what is beyond and before time in the divine persons of the Trinity. The soteriology that is dominant for the church and Christian theology implies the revelation of the kenosis moment, which is public and personal, sacred and secular. Kenosis occurs as a singularity that should underpin Christian leadership consider that the ruling bureaucratic class of the priestly class of Judaism treated Yeshua the peasant king with discontent. Among the key issues of discontent is the view of the messianism of Yeshua, who does not represent the outward symbols of Davidic royalty. However, the decision for the second person of the Godhead to become human is private, hidden and personal, fitting to his public appearance as saviour, which ends on the cross and resurrection. Thus, exalted as Lord as Peter explains on Pentecost (Acts 2:30-36): 'Therefore let all the house of Israel know assuredly that God has made this Jesus, whom you crucified, both Lord and Christ'.

The public appearance of a Christian leader is predicated on preceding events, for Christ; it was carried out through the messianic secret, ${ }^{2}$ which was public but hidden from the populous. The same instruction and character were typical of the kingdom of God. A kingdom born out of the tearing of the flesh and gushing blood of the poor messiah, dying at the hands of the state and religious authorities. However, the kingdom is 'neither here nor there' ${ }^{3}$ Just as the Spirit, which she comes from so does she behave as the Spirit - an invocation of omnipresence and transcendence that was revealed to Nicodemus.

Gerhart (2008:27) interviewed Biko concerning the formation of South African Student Organisation (SASO). Biko pointed out that the turning point in the formation of SASO was because of the 72-h restriction that black students needed to adhere at the NUSAS conference in July 1968. The interview expresses the dialogue between white students and black students. However, what is significant about the interview, on the subject of kenosis and leadership, is expressed in the ultimatum that black students gave to their white counterparts to show their solidarity with the oppressed. Gerhart (2008) records Biko saying:

A few of us were claiming that this was nonsense: we stay right here. Now what made the whites hysterical about what we were saying was that we said all right, when the vans come to collect us, whites should all lie in front of the vans so that they don't move. Then we'll allow the police to do what they like with blacks. You just lie there and don't move. The whites could not accept this. They saw it as an extremely irresponsible, radical line that didn't take into account the interests of the students on the restricted campuses. (p. 27)

Biko's challenge to white students reflects white people's inability to lay down privilege for the sake of black people. The fundamental point is that selfless sacrifice is a prerequisite in fighting for justice. The behaviour of leadership is deeply embedded in selflessness and sacrifice already accepted before public service. In South Africa, Christ has laid down before the police vans of the state. Suffering and sacrifice seem to be the most important episteme and hermeneutics for Christian leadership. West (2017:134-135) explains kenosis through the blues and James Brown performance. Brown often wanted to perform songs that the audiences wanted because his audiences were him. West points to that as kenosis. West (2017) argues:

That's serving others, giving of oneself, using what gifts you have in order to provide some light in a bleakness, in a darkness. That's what integrity is. Those who are committed to integrity are always up against the grain and in my own language, you're

2.The Messianic Secret is a concept that has been investigated in New Testament Studies, especially the nature of the synoptic gospels and the quest for the historical Studies, especially the nature of the synoptic gospels and the quest for the historical Jesus. Whatever it merits maybe or not what is sought to be expressed in its use in this article is the prect healing and death.

3.The Gospel of John 3, Yeshua discusses the bilateral nature and dialectical relations of visibility and invisibility. 
choosing the way of the cross and that cross signifies unarmed truth and the condition of truth is always to allow suffering to speak. It's unconditional, unapologetic love and that love is manifest in a willingness to pay a major price in saying what you say. (pp. 134-135)

West is correct in pointing that truth allows suffering to speak. The humanity of Christ proves that God's chosen saviour, the Son, has to suffer in order to deliver the oppressed. If God prior the flesh and in the flesh, choose Via Dolorosa, it is inconceivable why current Christian leadership is embedded in self and adoration. This makes the Christ preached in churches a metaphysical idea that allows lip service to Christ and the community.

\section{Pathways to black theology's kenosis in South Africa}

Kenosis, academically, has not been explicitly discussed in black theology. However, the kenotic praxis is found in the strivings and struggle of black people and oppressed groups. The death of many who stood for justice, liberation and freedom is a hallmark of a kenosis already in practice, true to the human condition, which Jesus incarnates into. Kenosis is imperative because the liberation of the oppressed is predicated on the selflessness and voluntary emptying of the leaders and the masses. Kenosis in black theology is more practical than theoretical. Cone (1993) correctly argues:

White theology is largely defined by its response to modern and post-modern societies of Europe and America, usually ignoring the contradictions of slavery and oppression in black life, black religious thought is the thinking of slaves and of marginalized blacks whose understanding of God was shaped by the contradictions that white theologians ignored and regarded as unworthy of serious theological reflection. (p. 2)

\section{Cone (1993) further asserts:}

Jesus was not alone in his suffering. Blacks were not alone in their oppression in the United States. Jesus was with them! He was God's black slave who has come to put an end to oppression. Herein lies the meaning of Jesus' resurrection. It means that the cross was not the end of God's drama of salvation. (p. 6)

While Cone points to the hermeneutical theology of black people, Biko (1978:61) seems to be correct when arguing that: 'It must also be noted that the church in South Africa as everywhere else has been spoilt by bureaucracy'. The crisis of the church seems to have moved from the communal and serving church in the Book of Acts. Biko (1978) asserts:

Material want is bad enough but coupled with spiritual poverty, it kills. And this latter effect is probably the one that creates a mountain of obstacles in the normal course of emancipation of the black people. (p. 30)

Leadership in black communities reveals the spread of bureaucracy that has affected the church as new emerging black ministers value wealth than serving the poor. Material wants are used as signals of spiritual poverty, and spiritual poverty encroaches the access of material wants. Today, when reading about the malpractices of (black) churches' acts of fraud, bullying, sexual abuses of women and children, commodified miracles ${ }^{4}$ it is clear that a thorough understanding on the person of Christ is missing. There is a need to reinforce kenosis, human value and a suffering leadership, which brought the poor and oppressed, the first followers of Christ, into the faith.

Perhaps because of the close historical ties of the church and state in South Africa, which defined the past, the socioeconomic and political developments of the society affect the church. Day (2012:107) pointed out that (black) churches have neglected service to the poor for neoliberal free-market values of pursuits of riches, an attitude now shared by the secular world and the church. Martin et al.'s (2011:4, 5) discussion on the prosperity Gospel in black communities reveals that there is more emphasis on immediate wealth and consumerism. Biko's position on material wants and spiritual poverty is reversed to disempower the poor. Day (2012) asserts:

Many black neo-Pentecostal and 'word of faith' preachers teach their parishioners that wealth should be seen as part of their rightful inheritance as God's children. They encourage their congregants to 'name and claim' God's promises of wealth and divine health for all Christians who have great faith. Such leaders correlate wealth with the quality of one's faith and obedience in God; wealth and health are the results of unwavering faith. Consequently, those who experience chronic illness or financial duress must lack faith in God's eternal promise of riches and abundance for God's children. (p. 109)

Barnes (2013:179) notes that divine healing in these churches is 'overshadowed by expensive cars, houses and mega churches'. On the political level, post-apartheid South Africa has signalled a distorted watershed moment. Bompani's (2006:1138) asserted that: 'The end of apartheid defined the end of churches engagement in the political arena, although not as actors supportive of the ANC project of nation building'. The South African religious Christian experience, especially in the inner city and black communities, sees the rise of churches that seek an immediate socio-economic encounter with God. However, the obstacles for these churches is that they disempower their believers. South Africa needs a suffering and kenotic leadership model with the increasing levels of conceit, selfishness and privilege that prevail with the widening of the buffer between the poor (powerless) and powerful. The matrix of power in South Africa and Africa is maintained by new colonial methods that preserve privilege. Kenosis requires relinquishing privilege (see Bekker 2006:3-4). The political arrangements that led to 1994 elections, which are affecting the country now, were arranged around black South Africans being peaceful to preserve the peace. The black consciousness movement while peaceful called for a direct confrontation. Mabasa (1984) correctly asserts:

4.Fake resurrection SABC (2019) News Exclusive, some congregants accuse Alph Lukau of staging miracles. Pastor Omotoso's rape trial continues, News 24. Pretoria Pastor of staging miracles. Pastor Omotoso's rape trial continues, News 24. Pretoria Pastor
convinces congregation to eat grass (2014). 'Snake Pastor' feeds dog meat to convinces congregation to eat grass (2014)
congregants for communion (News 24, 2018). 
Our peacefulness does not presuppose timidity. No timid people can become a nation. To augment our peacefulness we also need a militant spirit, a strong will and desire to survive in a violent and carnivorous world. (p. 26)

Mabasa is correct in noting that timidity is a negation to becoming a nation; theologically, the brutality of the cross did not restrict the incarnation of Christ. However, it reflected the understanding of power that South Africa needs today. Kenosis and suffering leadership require a relationship of practice and exercise. Kretzschmar (2002:52) argues:

Arguably, one cannot practise the relinquishing of power (Phil 2:1-11), if one has not first received and exercised personal power. Jesus could be a servant in John 13:1-17 precisely because he had been given power and he was fully conscious of his origin and destiny. Unlike many contemporary leaders, he was not suffering from lack of self-knowledge or an identity crisis. (p. 52)

\section{Conclusion}

Christian ethics in the biblical text shuns any form of sloganeering; Yeshua (Is 29:13, being referred to here in Mt 15) declared:

These people draw near to Me with their mouth, And honour Me with their lips, But their heart is far from Me. And in vain they worship Me, Teaching as doctrines the commandments of men. (vv. 8-9)

God's solidarity with the poor and oppressed is a kenotic moment, a singularity, which extends far from the wisdom tradition of the psalms, proverbs, ecclesiastics and other part of scriptural poetry that addressed the existential condition. Selflessness becomes a point of departure for the individual and the incarnation into being the other in the community.

\section{Acknowledgements}

This article is dedicated to the church in the current moment of great crisis and affirms the lessons from Christ.

\section{Competing interests}

The author declares that he has no financial or personal relationships that may have inappropriately influenced him in writing this article.

\section{Author's contributions}

H.M. is the sole author of this research work.

\section{Ethical considerations}

This article followed all ethical standards for a research without direct contact with human or animal subjects.

\section{Funding information}

This research received no specific grant from any funding agency in the public, commercial or not-for-profit sectors.

\section{Data availability statement}

Data sharing is not applicable to this article as no new data were created or analysed in this study.

\section{Disclaimer}

The views and opinions expressed in this article are those of the author and do not necessarily reflect the official policy or position of any affiliated agency of the author.

\section{References}

Barnes, S., 2013, Live long and prosper, 'How black megachurches address HIV/AIDS \& poverty in the age of prosperity theology', Fordham University Press, New York, NY.

Bekker, C.J., 2006, The Philippians hymn (2:5-11) as an early mimetic Christological model of Christian leadership in Roman Philippi, viewed 30 July 2019, from http:// www.regent.edu/acad/global/publications/sl_proceedings/2006/bekker.pdf.

Biko, S., 1978, I write what I like, The Bowerdean Press, London.

Bompani, B., 2006, “"Mandela Mania”: Mainline churches in post-apartheid South Africa', Third World Quarterly 27(6), 1137-1149. https://doi.org/ 10.1080/01436590600842449

Carson, R.A., 1975, "The motifs of "Kenosis" and "Imitatio" in the work of Dietrich Bonhoeffer, with an excursus on the "Communicatio Idiomatum"', Journal of the American Academy of Religion 43(3), 542-553. https://doi.org/10.1093/jaarel/ XLIII.3.542

Clifford, C.E., 2004, 'Kenosis and the path to communion', Jurist 64(2004), 21.

Cone, J.H., 1993, Cross and suffering: A black American perspective, Black Theology Project, viewed 13 June 2017, from https://www.sahistory.org.za/sites/default/ files/archive-files/BtMay93.1015.2296.007.001.May1993.4.pdf.

Day, K., 2012, Unfinished business: Black women, the black church, and the struggle to thrive in America, Orbis Books, Maryknoll, New York, NY.

Doncel, M.G., 2006, 'The Kenosis of the creator, his creative call and the created co-creators', European Journal of Science and Theology 2(4), 5-13.

Gerhart, G.M., 2008, 'Interview with Steve Biko', in A. Mngxitama, A. Alexander \& N.C. Gibson (eds.), Biko Lives!, pp. 21-42, Palgrave Macmillan, New York, NY.

Hayes, C., 2017, 'The Torah was not given to Ministering Angels': Rabbinic aspirationalism', in C. Fonrobert, I. Rosen-Zvi, A. Shemesh \& M. Vidas (eds.), Talmudic transgressions: Engaging the work of daniel boyarin, pp. 123-160, Brill.

Kessler, V., 2010, 'Leadership and power', Koers 75(3), 527-550. https://doi.org/ 10.4102 /koers.v75i3.95

Kierkegaard, S., 1941, Fear and trembling dialectical lyric, transl. W. Lowrie, Doubleday \& Co., New York, NY.

Kretzschmar, L., 2002, 'Authentic Christian leadership and spiritual formation in Africa', Journal of Theology for Southern Africa 113, 41-60.

Le Poidevin, R., 2013, 'Kenosis, necessity and incarnation', The Heythrop Journal 54(2), 214-227. https://doi.org/10.1111/j.1468-2265.2012.00796.x

Mabasa, T.L., 1984, Frank Talk 1(1), 3-28.

Martin, P.P., Bowels, T.A., Adkins, L. \& Leach, M.T., 2011, 'Black mega-churches in the internet age: Exploring theological teachings and social outreach efforts', Journal of African American Studies 15(2), 155-176. https://doi.org/10.1007/s12111 011-9181-2

Pardue, S., 2012, 'Kenosis and its discontents: Towards an Augustinian account of divine humility', Scottish Journal of Theology 65(3), 271-288. https://doi.org/ $10.1017 /$ S0036930612000117

Rolston, H., 2001, 'Kenosis and nature', in J. Polkinghorne (ed.), The work of love: Creation as Kenosis, pp. 43-65, Eerdmans Publishing Co., Grand Rapids, MI.

Ruether, R., 1983, Sexism and God-talk: Toward a feminist theology, SCM Press, London.

South African Broadcasting Corporation (SABC), 2019, News exclusive: Some congregants accuse Alph Lukau of staging miracles, viewed n.d., from https:// www.youtube.com/watch?v=yAOif6w-nx8.

West, C., 2017, 'Intellectual vocation and political struggle in the trump moment', Journal of Political Theory \& Philosophy 1(14), 127-140 